\title{
Which Countries Have More Open Governments? Assessing Structural Determinants of Openness
}

\begin{abstract}
An increasing number of countries are adopting open government reforms, driven, in part, by the Open Government Partnership (OGP), a global effort dedicated to advancing such initiatives. Yet, there is still wide variation in openness across countries. We investigate the political, administrative, and civic factors that explain this variation, using countries' fulfillment of OGP eligibility criteria as a proxy for minimum standards of openness. We find that countries with strong constraints on the executive and high levels of citizen education have governments that are more open. A dense network of civil society organizations is associated with more budget transparency and higher civil liberties, but not with access to information or asset disclosure laws. The results suggest that if the value of openness is to be translated in practice, it is not enough to have capable bureaucracies - countries also need informed citizens and strong oversight of executive agencies.
\end{abstract}

Keywords: open government, transparency, access to information, global initiatives 


\section{Which Countries Have More Open Governments? Assessing Structural Determinants of Openness}

On his first day in office in 2009, President Obama issued the Open Government Directive, which encouraged public agencies to be more transparent, participatory and collaborative (McDermott, 2010). In 2011, he launched the Open Government Partnership (OGP) at the U.N. General Assembly, together with six other heads of state. The OGP is a global multi-stakeholder partnership that aims to "secure concrete commitments from governments to promote transparency, empower citizens, fight corruption, and harness new technologies to strengthen governance" (Center for American Progress, 2016, p. 2). Today, 70 governments are active OGP members, and they are joined by myriad non-governmental and international organizations that want to advance government openness around the world. Even outside of the OGP initiative, more and more national and local governments are adopting various open government measures, from open data portals to using online tools to consult and involve citizens and policy-makers (Wirtz and Birkmeyer, 2015).

As it increased in popularity, open government (OG) has been touted not just as a way of improving government performance and citizen participation, but also as a new form of or paradigm for governance (OECD, 2016). While scholars have identified some determinants of overall institutional quality in a country (e.g, Islam \& Montenegro, 2002; Serra 1613/2011), relatively little is known about the contexts in which open government specifically is likely to flourish. Public administration research on open government has examined its conceptual dimensions (Meijer, Curtin, \& Hillebrandt, 2012), the organizational drivers of open government at the local level in the US (Grimmelikhuijsen \& Feeney, 2016), and US open government policy (McDermott, 2010; Piotrowski, 2017, 2018). However, few have asked why some national 
governments are more open than others. Understanding which country-level, macro-structural factors and "large forces" shape government openness is, however, critical to the pursuit of OG efforts (Roberts, 2015). It can help advocates, practitioners, and researchers understand the contexts in which OG reforms are more likely to take hold and be successful, as well as how to improve the overall preconditions for government openness in a country.

Hence, the overall research question for this paper is which political, administrative, and civic factors are associated with more open governments around the world. Part of the challenge in assessing cross-national correlates of open government is the lack of an established measure of openness that is comparable across countries. To date, public administration research about the drivers of OG primarily has focused on measures of website openness (e.g., Grimmelikhuijsen \& Feeney, 2016; Welch \& Wong, 2001; Wong \& Welch, 2004), or budget transparency (Wehner \& de Renzio, 2013; Alt \& Lassen, 2006; Rios, Bastida, \& Benito, 2014; Bolívar, Perez \& Hernandez, 2006; Bolívar et al., 2013), and predominantly at the local or subnational government level (Grimmelikhuijsen \& Feeney, 2016; Grimmelikhuijsen and Welch, 2012; Ortiz-Rodriguez et al., 2015). The OGP offers a new option for such a cross-national measure of openness in the form of the eligibility criteria that countries have to meet to join the partnership. We leveraged these eligibility scores to build a dataset spanning five years and 121 countries.

The next section introduces the OGP and approaches to measuring open government, and explains how the OGP eligibility criteria serve as a measure for a minimum standard of openness. We then review extant theoretical and empirical literature on macro-level determinants of government openness and transparency, and develop a set of hypotheses about the political, administrative, and civic factors that are most strongly associated with government openness. We find that two structural factors are the strongest predictors of openness across all measures used: 
executive constraints and citizen education. A dense network of civil society organizations is associated with de facto (in-practice) measures of openness, but not with de jure measures. Other factors often assumed as important for different aspects of openness, such as political competition and administrative traditions and capacity are not significant related to any of the measures of openness used in our dataset. We conclude with recommendations for further crossnational research on the structural drivers of government openness, as well suggestions on how the OGP could further strengthen the global openness agenda.

\section{The OGP and Government Openness}

In 2011, the governments of Brazil, Indonesia, Mexico, Norway, the Philippines, South Africa, the United Kingdom, and the United States signed the Open Government Declaration and started the Open Government Partnership (OGP). The goal of the OGP is to encourage and help governments around the world adopt and implement open government initiatives by offering a global knowledge and cooperation platform for openness activists. Governments that want to join must endorse the Open Government Declaration, meet the eligibility criteria discussed below, and formally apply to the Steering Committee ${ }^{i}$ to become members (OGP, 2018a). Once they join, they have to prepare an Open Government Action Plan every two years through a consultative process that involves civil society and openness activists. The Action Plans include time-bound measures (commitments) to increase openness, which can range from the online publishing of various kinds of data in an open format to setting up consultation mechanisms to include indigenous (and other) groups in policy making (OGP, 2016).

OGP aims to be a global knowledge platform that supports and encourages governments to become more open (Fox, 2013). Yet, it also acknowledges the dangers of "open-washing," that is, governments joining the OGP as a way to increase their international status by paying lip- 
service to openness, while engaging in less-than-open, sometimes outright repressive behavior. To avoid or limit "open-washing," the OGP has built in a series of "safe-guards" both in terms of who can join and how member countries behave once they have joined. To ensure participation in the preparation of the action plans, the OGP has developed a set of guidelines for civil society consultation. The quality and the implementation of the action plans and the degree of civil society participation is monitored by independent experts from participating countries, who produce progress reports every two years. The reports are validated and centralized by the OGP's Independent Reporting Mechanisms (IRM), an independent body affiliated with the OGP and overseen by an International Experts Panel (IEP) composed of global transparency, participation, and accountability experts (OGP, 2018b).

As another safeguard, the OGP requires governments that want to join to "demonstrate a minimum level of commitment to open government principles" (OGP, 2018a). They do so by meeting a set of four eligibility criteria agreed-upon by the Steering Committee. ${ }^{\text {ii }}$ These criteria arguably represent minimum standards of government openness, and reflect the currently dominant interpretation of openness as transparency and participation (Meijer, Curtin and Hillebrandt, 2012). ${ }^{\text {iii }}$ The first three OGP eligibility criteria assess the level of government transparency in three key areas: access to information, budget transparency, and disclosure of public officials' assets. The first two criteria reflect the areas where there has been the most global advocacy and progress on transparency. Laws guaranteeing citizens' access to information have become a global norm (Ackerman \& Sandoval-Ballasteros, 2006), and budget transparency has become an increasingly popular subject of global advocacy and reform (Wehner \& de Renzio, 2013). Public disclosure of officials' assets has also been advocated by researchers and international organizations as an important addition to the transparency toolbox (Djankov et al., 
2010; OECD, 2011). The fourth eligibility criterion captures whether the country has an environment conducive to public participation, that is, whether civil liberties are respected enough to allow for citizens' voice without repercussions.

The OGP tries to strike a delicate balance between inclusiveness and selectivity through the eligibility criteria (Fox, 2013), while at the same time grappling with the inherent challenges of finding comparable cross-national measures of such complex concepts as transparency and participation (Michener, 2015). In doing so it relies on measures that assess legal provisions for access to information and asset disclosure ("in law" or de jure measures), and on measures that assess the publication of key budget documents as well as respect for civil liberties in practice ("in practice" or de facto measures). To calculate eligibility scores, the IRM draws from established and reputable international organizations for each criterion: the International Budget Partnership for budget transparency, Right2INFO for access to information, the World Bank for asset disclosure, and the Economist Intelligence Unit for civil liberties.

Despite their limitations, the OGP eligibility criteria are arguably the best currently available cross-national proxies or standards for "minimum" government openness. Normatively, they capture the two features of open government on which there is the strongest academic and policy consensus: transparency and participation. Procedurally, they are the closest to a global consensus about the minimum features of open government, given their selection by a Steering Committee that includes governments and civil society representatives of countries and organizations invested in advancing openness. Empirically, the aggregate OGP eligibility score correlates significantly with other cross-national indicators of openness, such as those measuring the release of economic and social data by governments (Hollyer, Rosendorff \& Vreeland, 2014) 
or those that aggregate various dimensions of transparency, participation and accountability (Williams, 2015 ${ }^{\text {iv }}$.

\section{Politics, Administration, or Civics: What Explains Government Openness?}

Public administration literature has long emphasized transparency and openness as fundamental democratic values (Piotrowski, 2008; Hood \& Heald, 2006). Yet, it has taken a long time to translate these values into policy and practice, and the battle is ongoing. Transparency, often codified in Freedom of Information laws, has perhaps the longest history - the first such legislation was adopted in $18^{\text {th }}$ century Sweden. Globally, however, FOIA adoption only took off in the 1990s (Roberts, 2006). Global advocacy around and adoption of budget transparency is an even more recent phenomenon, beginning in the early 2000s and driven by various international organizations such as the Organization for Economic Cooperation and Development, the International Monterey Fund, and the International Budget Partnership (Wehner \& de Renzio, 2013). Asset disclosure is perhaps one of the latest additions to the transparency toolbox, and fewer governments have adopted public asset disclosure (Djankov et al., 2010). Participation is a fundamental democratic value, but enshrining participation in administrative matters, as opposed to political participation, in public legislation and practice is also a more recent phenomenon (Nabatchi and Leighninger, 2015).

Governments tend to resist transparency and openness provisions, as they also face strong incentives for secrecy (Roberts 2006; Darch \& Underwood, 2010). David Cameron, the former British Prime Minister, famously described the passage of FOIA as the biggest mistake of his premiership. In the US, Congress had to override a presidential veto to pass FOIA in 1966. For executives and public agencies, openness requires giving up some degree of control by increasing their vulnerability to scrutiny, and thus criticism, by the public, in addition to 
increasing costs and slowing down decision-making (Moynihan, 2003; de Graaf \& Paanakker, 2014). What then explains the popularity of transparency and openness initiatives and legislation? In the following sections, we review the literature on political, administrative, and civic factors that may contribute to OG and develop a series of hypotheses for testing.

\section{Political Factors}

Political factors, such as political regime and culture, are often associated with government openness (e.g., Inglehart and Welzel 2003; Wehner \& de Renzio, 2013; Hollyer et al, 2014). First, transparency and government openness more broadly are fundamental democratic values. Second, they can be a reaction to citizen demands or expectations: governments can use them to "signal" honesty, democratic commitment, and thus try to increase or restore public trust (Roberts, 2006; Michener, 2011; Berliner, 2014; Author, 2017). Third, they can act as a check on (excessive) executive power (Roberts, 2015). Indeed, historically, transparency and openness-enhancing provisions, such the Freedom of Information Act (FOIA) or public disclosure and notice-and-consultation requirements in Administrative Procedure Acts (APAs) have been a reaction to expansions in executive power and autonomy, and/or perceptions of government failures and lack of accountability (Roberts, 2015). Fourth, they offer benefits for legislators and for higher-level officials to hold public agencies to account by reducing “information asymmetries," thus reducing monitoring costs by complementing top-down "police patrol" monitoring with bottom-up, fire-alarm monitoring (McCubbins \& Schwartz, 1984).

The many different channels through which democracy and openness can be related suggest not only that democracy, broadly speaking, matters for openness, but that different features of democratic systems could matter differently. Two such features stand out in the theoretical and empirical literature: political competition and executive constraints. Political 
competition strengthens incentives for openness as parties compete more intensely with each other on who can credibly promise more transparency, participation, or openness and/or have incentives to institutionalize these as ways to constrain the power of rulers and of their political rivals (Berliner, 2014). These incentives are even stronger under divided government ${ }^{\mathrm{v}}$ (McCubbins \& Schwartz, 1984), and when programmatic parties include openness in their electoral agenda. However, since openness constrains or creates costs for the ruling party, opposition parties have an inherent incentive to support openness provisions even if these are not officially part of their political platform. Both quantitative and qualitative empirical studies have found a consistent correlation between higher political competition and the adoption of access to information legislation (Berliner, 2014; Author, 2017), as well as budget transparency (Alt \& Lassen, 2006; Wehner \& De Renzio, 2013). However, some studies have also found that high political competition is associated with lower transparency in some cases. For example, Cicatiello, De Simone, \& Gaeta (2017) argue that fragmentation of parties in the legislature increases coordination costs and makes it more difficult for legislatures to exercise their accountability function. Ingrams (2018) find that in countries which have recently democratized low political competition coupled with strong civil society which is more conductive to ATI adoption than high political competition.

These latter findings suggest that it might not be the level of political competition alone that matters for openness, but the degree to which legislatures and other accountability institutions have strong, institutionalized avenues for holding the executive and public agencies to account. Thus, it is possible that political competition (also) has an indirect effect on transparency and openness by strengthening other accountability institutions, and that it is not just the level of political competition at a certain point in time which matters, but its robustness 
and continuity over time (Grzymala-Busee, 2006; Author, 2017). There is some cross-national evidence on the importance of executive constraints for some measures of openness. For example, Rios, Bastida, and Benito (2014) find that countries with stronger legislative oversight over the budget have higher fiscal transparency, while Willams (2009) finds that countries with higher constraints on the executive release more information to the public.

Therefore, our first two hypotheses expand on existing research to test the importance of these two structural features of the political system for the OGP's measures of openness:

H1. Countries with higher levels of political competition will have higher degrees of government openness than countries with lower levels of political competition.

H2: Countries with stronger executive constraints will have higher levels of government openness than countries with weaker executive constraints.

\section{Administrative Factors}

Even though democracy and openness are normatively related, not all democracies have been equally quick or enthusiastic in embracing transparency or participation. For example, some established democracies, such as the UK and Germany joined the FOIA bandwagon relatively late (2000 and 2005 respectively). One explanation is that the degree of transparency in government depends not only on political but also on administrative factors (Darch \& Underwood, 2010; Pasquier \& Villeneuve, 2007). Two such factors stand out: administrative traditions, including politico-administrative relations and dominant forms of bureaucratic accountability, and the strength or capacity of the public administration.

There is substantial cross-national evidence that countries with common law traditions have higher levels of fiscal transparency (Wehner \& de Renzio, 2013; Alt \& Lassen, 2006; Rios et al., 2014; Ortiz-Rodriguez et al., 2015; Bolívar et al., 2006; Bolívar et al., 2013). The reason 
why is not entirely clear. Some scholars attribute it to the higher market-orientation of common law countries and their tendency to place greater restraints on the state, and specifically on executive power (e.g., Alt \& Lassen, 2006; La Porta et al., 1999; Wehner \& de Renzio, 2013). Others attribute the difference to the fact that the delegation of budget authority to the executive is higher in Westminster-style countries than in civil law ones, and thus legislatures tend to impose more transparency and reporting provisions to exercise their oversight function (e.g., Rios et al., 2014). Still others argue that the difference is due to the more open and less legalistic administrative culture in Anglo-Saxon countries, which puts more emphasis on output control and accountability for performance than continental European countries do (e.g., Bolívar et al., 2006).

There is less research on the relationship between common law and other forms of openness, but if Anglo-Saxon countries do indeed have a more open administrative culture, then the relationship should hold also for other measures of openness. For example, Ortiz-Rodriguez and colleagues (2015) find that local governments in countries with Anglo-Saxon administrative traditions publish more information about policy sustainability than those in countries with continental European administrative traditions due to a more "open administrative culture," including more emphasis on citizen participation and on performance monitoring. While common law and Anglo-Saxon administrative traditions are somewhat conceptually distinct, empirically, they tend to go hand in hand, as both are found in the same set of countries - mostly former British colonies. Theoretically, there are also strong reasons to believe that the two are highly related, since administrative systems are grounded in law and affected by judicial practice and legal philosophy. Thus, we test whether the relationship holds beyond budget transparency through our third hypothesis: 
H3: Countries with common law and Anglo-Saxon administrative traditions have higher levels of government openness than countries with other traditions.

Regardless of administrative tradition, government openness also requires administrative capacity for record keeping, information management, data analysis, and processing and responding to information requests (Darch \& Underwood, 2010). For example, Grimmelikhuijsen and Feeney (2016) and Grimmelikhuijsen and Welch (2012) find that municipalities with higher organizational capacity also have higher levels of website-mediated transparency, both in the US and in the Netherlands. At the same time, high bureaucratic capacity can also be used to increase secrecy and resist openness. For example, in a sample of fourteen countries, Welch \& Wong (2001) and Wong \& Welch (2004) find a U-shaped relationship between strong bureaucracies and website openness of key public agencies.

At the central government level, there is surprisingly little systematic cross-national research on whether governments with higher capacity also adopt more openness measures. One of the few exceptions is Williams (2009), who investigates whether countries with higher bureaucratic quality disclose more aggregate macro-economic, social, and financial information. He finds that bureaucratic quality increases after governments start disclosing more information, rather than the other way around. While seemingly counter-intuitive, this could be because more openness enables more accountability, thus leading decision-makers to strengthen the capacity of the public sector to respond to citizen demands. While the evidence is mixed, we test the intuitive hypothesis that:

H4. Countries with higher levels of administrative capacity will be more open than countries with lower levels of administrative capacity. 


\section{Civic Factors}

Political competition, executive constraints, and administrative culture and capacity are thus expected to make governments more willing and able to enact openness measures, that is, they increase the "supply of openness." Yet, if there is no "demand" for openness from citizens, it is unlikely that the "supply" will emerge by itself. For example, parties and leaders have few reasons to campaign as "openness candidates" or promise more transparency and participation once in government if they do not believe that voters will reward such a stance. Even if the bureaucracy has the capacity to publish large amounts of data online or engage citizens in public affairs, there is little use in doing so if citizens do not take advantage of the opportunities offered. Levels of education are key in this regard. At the very least, citizens need to be able to read and interpret the information released by the government (Etzioni, 2014; Worthy, 2015). Beyond simple comprehension of information, better educated citizens are more likely to participate in social and political life in general (Glaeser, Ponzetto, \& Shleifer, 2007) and more likely to demand more government transparency and actively try to hold the government to account (Botero, Ponce, \& Shleifer, 2013).

Indeed, in countries with higher levels of education, governments release more and better information to the public (Williams, 2009). There is no similar cross-national evidence for the links between education and other key aspects of openness, such as budget transparency or FOIA adoption, since existing cross-national studies just control more broadly for socio-economic factors through GDP per capita rather than directly testing for the effect of education (Wehner \& de Renzio, 2013; Rios et al, 2014; Berliner, 2014). One exception is Lee and colleagues (2011), who find that higher human capital is associated with e-government development. Given the 
theoretical importance of education for openness, we test whether the relationship holds for a broader set of measures through our fifth hypothesis:

H5: Countries with higher levels of education will have more open governments than countries with lower levels of education.

Yet, even in developed countries with high levels of education, there are limits on how well individual citizens can understand what government is doing, let alone have the "rare combination of time, interest, and skills" needed to use government information for demanding and enacting accountability (Worthy, 2015, p. 9; Roberts, 2012). As Etzioni (2014) puts it, the expectation that releasing data to the public will by itself "solve" democratic accountability problems ignores the very real time- and knowledge-constraints citizens face. Therefore, "information intermediaries" - organizations that can process and interpret government data and communicate it to the public or to the relevant accountability institutions - are necessary (Zyl, 2014; Worthy, 2015).

Two types of intermediary organizations are essential: media and civil society organizations (CSOs). Journalists and CSOs are not only some of the main users of data released by the government, but are also some of the most active advocates for transparency. This has been particularly visible in the FOIA movement (Ackerman \& Sandoval-Ballasteros, 2006; Michener, 2011). Although corporate control, fake news, and propaganda sometimes prevent the media from appropriately functioning as good intermediaries between citizens and governments, press freedom still plays a key role in ensuring effective government transparency (Fairbanks, Plowman, \& Rawlins 2007; Lindstedt \& Naurin, 2010). CSOs also have been key in advancing other global transparency initiatives (Brockmeyer \& Fox, 2015) or acting as advocates for citizen participation (LeRoux, 2007; Denhardt \& Denhardt, 2000). Even the rapid take-up of the OGP 
by eligible countries has been credited in part to the existence of national and international networks of civil society activists and government officials (Fox, 2013).

Thus, the last two hypotheses capture the importance of information intermediaries for open government:

H6: Countries with stronger civil societies will have more open governments than countries with weaker civil societies.

H7: Countries with higher levels of press freedom will have more open governments than countries with lower levels of press freedom.

Before presenting the data and methods used to test these hypotheses, it is useful to summarize the arguments and hypotheses presented above. Governments will be more open when structural factors incentivize both the "supply" of openness by executives and bureaucrats and the "demand" for openness from citizens, intermediary organizations, and legislators. On the “supply" side, political incentives for openness will be high where high levels of political competition and executive constraints ( $\mathrm{H} 1$ and $\mathrm{H} 2)$ empower legislators to enact openness provisions to increase accountability of the executive, or where executive leaders "compete" on openness in electoral campaigns, or use openness measures to increase their popular support. Legislators and executives in more open administrative cultures might be more prone to adopt openness provisions (H3). Yet, transparency is not costless, and public agencies need capacity to comply with openness requirements (H4). More highly educated citizens are more likely both to use and to demand more avenues for openness, and citizen demand is amplified by intermediary organizations such as CSOs and a free press (H5, H6, and H7). In other words, government openness is more likely when there already is a somewhat functioning "accountability triangle" between citizens, policy-makers, and bureaucrats. 


\section{Data and Methodology}

As noted, the OGP eligibility criteria can be seen as minimum standards of openness. Thus, we use the scores for the four eligibility criteria (budget transparency, access to information, asset disclosure, and civil liberties), as well as the share of the total OGP eligibility score for each country as our dependent variables. The data come from the OGP Independent Reporting Mechanism (IRM) site, ${ }^{\mathrm{vi}}$ which compiles the data and calculates the scores for all countries from a variety of sources. Each criterion, the scoring process, and the original sources of data are summarized in Table 1. Each eligibility criterion is assigned a score from 0 (lowest) to 4 (highest), and the total eligibility score is the sum of the scores on each criterion. Only countries that achieve at least $75 \%$ of their total possible eligibility points can join the OGP. We use the share of total eligibility points as our main dependent variable, measured on a scale from 0 to 1 .

[Table 1 here]

Other than three variables (administrative traditions, bureaucratic quality, and the number of CSOs), all of the independent and control variables are from the 2018 Quality of Government (QoG) dataset (Teorell et al., 2018), which compiles about 2500 country-level variables from a variety of sources. We have two political system variables. First, we operationalize political competition as the share of seats held by all opposition parties in the national legislative. The original data comes from the Database of Political Institutions, and is included in the QoG dataset (Teorell et al., 2018). Second, the executive constraints indicator comes from Polity IV, and assesses on a scale from 1 (lowest) to 7 (highest) "the extent of institutionalized constraints on the decision-making powers of chief executives, whether individuals or collectivities" (Teorell et al., 2018, p. 479). 
We also have two administrative variables. First, we use La Porta and colleagues' (1999) dummy variable for common law traditions as a proxy for Anglo-Saxon administrative tradition. Second, to assess administrative capacity we use the International Country Risk Guide's (ICRG) Bureaucratic Quality Index, which measures (on a scale of 0 to 4 ) whether the public administration has "the strength and expertise to govern without drastic changes in policy or interruptions in government services" (The PRS group, 2012, p. 7).

We include three civic variables. First, citizens' education level is measured by the average years of educational attainment (Teorell et al., 2018). Second, the strength of civic society is measured using the log value of Grimes's (2013) measure of number of CSOs per million inhabitants. ${ }^{\text {vii }}$ We use a direct measure of civil society density rather than of the environment for civil society, such as freedom of association, since the latter is likely to be highly correlated both with press freedom and with civil liberties. Finally, we use Freedom House's press freedom index (Teorell et al., 2018). ${ }^{\text {viii }}$

We also use several control variables, including GDP per capita (current US dollars, logged) and population (logged). In addition, global policy diffusion is a key driver of transparency and open government reforms across countries (Roberts, 2006; Lee et al., 2011; Welch \& Wong, 2001; Berliner, 2014) - arguably one that the OGP itself seeks to encourage. We do not include diffusion-related variables in our theoretical framework since we investigate the structural determinants of openness at the country level rather than the process or the patterns of diffusion across countries variables. However, we do acknowledge that countries that are better integrated into the global economy and polity are also more susceptible to international policy diffusion, and thus more likely to be open. Hence, we also control for a country's 
integration into the global system using the KOF Index of Globalization, which captures political, economic, and social globalization of countries (Teorell et al., 2018).

We constructed a data set of 121 countries for which data is available in the IRM OGP dataset over five years, from 2011, when the OGP started, to 2015. The list of countries included is available in Annex 1. Table 2 presents the summary statistics for all the variables. OGP budget transparency and asset disclosure scores have missing values in some years, since the organizations that collect the source data on which the OGP scoring is based do not cover all countries in all years. This results in differences in the $\mathrm{N}$ in these two models. As a robustness test we also ran the models for the DVs on the same restricted sample as the one for budget transparency, but the results do not change substantially. Furthermore, as Wehner and de Renzio (2013) argue for the Open Budget Index (OBI), on which the OGP budget transparency score is based, there are no systematic differences between countries included and not included in the OBI sample.

[Table 2 here]

To test our hypotheses, we employ OLS regressions ${ }^{\mathrm{ix}}$ with year dummies and clustered standard errors by country to account for year effects and country-level heterogeneity. ${ }^{\mathrm{x}}$ We do not use two-way panel fixed effects since one of the key independent variables, the Anglo-Saxon administrative traditions, is constant across time. Moreover, conceptually, we look at structural factors (i.e., factors that tend to be relatively stable over short time-frames); thus, year-to-year changes are relatively small and do not offer enough variation for a fixed effect model.

\section{Results and Discussion}

Table 3 below presents the results of our models. Only two explanatory variables are significant regardless of the openness measure used: executive constraints and educational 
attainment. Surprisingly, neither of the administrative variables are significant in any of the models. Intermediary organizations - CSOs and a free press - are significant for the overall eligibility score, but they matter differently for different measures of openness. The remainder of this section discusses each of our hypotheses tests in turn.

[Table 3 here]

\section{Political factors}

We do not find evidence for H1, which asserted that countries with higher levels of political competition will be more open, as political competition is not significant in any of the models. This suggests that short term, year-to-year political competition may not matter most for openness, but rather the robustness of political completion over time and its effect on executive constraints. Disentangling the dynamic through which political competition affects openness is a fruitful area for further research. Executive constraints, in the other hand, are significantly associated with more openness for all aspects of openness measured (H2 supported). Our data do not allow us to identify the direction of causality, that is, (i) whether legislatures that already exercise a high level of executive control are most likely to adopt openness requirements, or (ii) whether the adoption of openness provisions enables legislatures to better exercise their accountability function. It is likely that the relationship runs both ways: the more tools legislatures have to demand the release of information, the stronger the constraints on the executive, and the stronger the constraints on the executive, the better positioned legislatures are to demand more transparency. Indeed, Rios and colleagues (2014) find evidence of endogeneity between strength of legislative oversight of the budget and level of budget transparency. Similarly, Williams (2009) finds that executive constraints lead to the release of more 
government information to the public in the long term, while in the short term, more information disclosure contributes to stronger executive constraints.

\section{Administrative Factors}

The results suggest that the administrative factors included in our models have little influence on the "supply" of openness. Common law and Anglo-Saxon administrative traditions are not significantly associated with openness in any of the models (H3 not supported). This is somewhat surprising, at least for budget transparency, given the empirical findings from other studies (Wehner \& de Renzio, 2013; Alt \& Lassen, 2006; Rios et al., 2010). One reason could be again that we control directly for executive constraints - one of the main channels through which common law is supposed to be associated is with higher budget transparency. To determine whether the lack of significance can be explained by the different time-frame covered in our study compared with the studies that find a positive correlation between common law and budget transparency, we also ran the models separately for each year. We found that the common law variable is significant in 2011, but not after. This suggests that while government openness might have been higher in Anglo-Saxon countries earlier on, as budget openness has become more of a "global norm" this distinction is less important.

Bureaucratic quality (BQ) is also insignificant (H4 not supported). Current studies that find a link between administrative capacity and openness tend to use proxy measures, such as population size of local government (Ortiz-Rodriguez et al, 2015; Grimmelikhuisen and Feeney, 2016) or GDP per capita (Wehner \& de Renzio, 2013; Hollyer et al, 2014). GDP per capita is significant for the overall eligibility score, access to information, and asset disclosure, but with a negative coefficient. While counterintuitive, this is not entirely surprising. The lack of significance is in line with research that finds no association between GDP and some measures 
of openness at the cross-national level (e.g., Berliner, 2014; Lee, 2011). The negative coefficient for access to information and asset disclosure could reflect the patterns of global diffusion of the two policies. For example, the most recent adopters of FOIA have been developing countries and lower-income countries (Ackerman \& Sandoval-Ballasteros, 2006). While fewer countries have public asset disclosure (Djankov et al, 2011), this measure has also been part of the transparency toolkit advocated by international organizations to fight corruption especially in developing countries (OECD, 2011).

\section{Civic Factors}

On the "demand side" of open government, education is significantly and positively associated with all openness measures. This suggests that more highly educated citizens are more likely to demand openness from their government (H5 supported). While citizens need literacy, numeracy, and analytical skills, for example, to use the information and data published by governments, the theoretical reasons to believe that the direction of causality runs from openness to education are weaker. A more likely explanation is that governments that provide broad-based public services, including access to education, are also more likely to provide other "public goods," such as openness, to citizens. This is a more plausible assumption and one that merits more investigation, given the strength of the relationship between openness and education.

The relationship between the strength of intermediary organizations and open government is less consistent. CSO density is significant for budget transparency and civil liberties, as well as for the overall eligibility score, but not for access to information and asset disclosure (H6 supported only for some measures of openness). Conversely, press freedom is significant for access to information, civil liberties, and the total eligibility score ( $\mathrm{H} 7$ supported

only for some measures of openness). The lack of significance of CSO density for the access to 
information measure is somewhat puzzling, given the case-study evidence that CSOs have been key drivers of FOIA adoption around the world (Ackerman \& Sandoval-Balasteros, 2006; Michener, 2011). One possible explanation is that only a handful of specialized NGOs, such as Article XIX or other freedom of expression, democracy, and human rights organizations have been the main advocates of adopting provisions enshrining the right to information into law. Thus, while a broader set of NGOs, private companies, and individual citizens might actually use FOIA, the general density of CSOs is less relevant for whether a country has such a law or not. Indeed, the fact that CSO density is associated with the de facto (in practice) measures of openness (budget transparency and civil liberties), but not with de jure (in law) ones (access to information and budget transparency) suggests that while a few dedicated NGOs might successfully push for the adoption of openness legislation, ensuring compliance with openness provisions requires a denser network of civic and media organization who use these tools repeatedly and maintain pressure on public agencies to comply.

\section{Conclusions and Implications}

The article sought to answer the question "why are some national governments more open than others?" using data from the Open Government Partnership. It adds to the empirical literature on open government by assessing the structural determinants of openness at the country level, based on a larger dataset and a broader set of openness measures than existing crossnational studies on the determinants of transparency (e.g., Rios, Bastida, and Benito, 2014; Wenher and De Renzio, 2013). We find that two structural factors are the strongest predictors of even minimum levels of openness: executive constraints and citizen education. At the most general level, this reinforces the message that political and civic characteristics of a country matter for government openness as much, or even more, than administrative capacity and 
traditions (Welch \& Wong, 2001; Wong \& Welch, 2004; Rios et al., 2014; Ortiz-Rodrigues et al., 2015; Bolívar et al., 2006). While our data do not allow us to disentangle the direction of causality, the results suggest plausible hypotheses and important avenues for further research. They also provide some insights to practitioners who seek to advance the cause of open government around the world.

First, the study confirms the importance of democracy for openness found in previous cross-national research (e.g., Wehner \& De Renzio, 2013, Hollyer et al., 2014). While not surprising, in these "dark times" of seeming democratic recession around the world (Diamond 2015), this "simple" finding is itself important as a reminder that government openness is inseparable from democracy both normatively and empirically. We further unpack this relationship by adding empirical evidence about the importance of a hitherto understudied aspect of democracy: constraints on the executive, which is one of the two strongest predictors of openness in our study. Where such constraints are weak, it is unlikely that legislators will have the ability or incentives to demand transparency from reluctant executives. Where these are strong, a "virtuous circle of openness" could emerge, where transparency also enables legislatures and independent accountability institutions to perform their oversight function better.

Second, we show that civic factors also matter for government openness. The average education level of citizens is the strongest and most consistent predictor of government openness in our models, across time frames and measures used. Future studies on determinants of openness could benefit from including citizen education more clearly as an explanatory variable in theoretical models to disentangle the causal mechanisms through which education and openness are related. The density of civil society organizations also matters, but it matters more for some measures of openness than for others. One of the more striking findings is that a dense 
network of CSOs is associated with the de facto measures of openness (publication of key budget documents and respective for civil liberties), but not de jure ones (legal provisions for access to information and asset disclosure). This suggests that research on implementation of openness provisions could benefit from looking more specifically at the role that civil society actors and media can play in increasing administrative compliance with openness provisions. The findings also suggest it is not enough to have an environment that is conducive to civil society activism the density of civic organizations also matters. This is in line with the literature on the importance of civic organizations for good governance more broadly (Denhardt \& Denhardt, 2000; Putnam, 2001; Skocpol 2013) but has been somewhat understudied in cross-national studies of openness.

The findings of this article also suggest further avenues for leveraging the OGP to advance the open government research agenda. One salient issue is the distinction between inlaw and in-practice openness. One challenge in further investigating the determinants of de facto openness is the lack of reliable cross-national data on compliance with openness provisions, such as access to information and asset disclosure requirements. This is due, at least in part, to the methodological challenges and the high costs of such an exercise (Piotrowski, 2008; Michener, 2015). However, the OGP is perhaps better positioned than any other initiative to spur such a data collection effort. Some examples and suggestions from academia and practice for how to collect such data already exist, for example, by placing the same information requests across countries to collect data on speed and accuracy of response (Djankov et al., 2010 for asset disclosure; OSJI, 2006 for access to information). While not perfect, such examples illustrate options both for gathering better cross-national data on transparency in practice as opposed to in 
law, and for defining more "ambitious" OGP requirements to catalyze improvements in the practice of transparency.

Finally, the findings on the importance of civic and political factors for government openness also have implications for OGP practitioners and advocates. The OGP is indeed increasingly taking measures to encourage an openness-enabling civic and political environment among its member countries. Among other things, it re-emphasized the need for OGP members to protect civic space, set up a policy for responding to CSO complaints from member countries, and strengthened the participation guidelines for the action plans. The findings of this article suggests some additional options for encouraging a "virtuous circle of openness." First, since education emerged as the strongest predictors of openness, OGP action plans could include more open government measures targeted at the education sector. Indeed, there is evidence that, if done right, increasing transparency and participation in education can lead to improved education outcomes (Fox, 2015; Kosack \& Fung, 2014). Second, while the OGP itself cannot change the balance of power or the statutory relationship between the legislature and the executive, the importance of executive constraints suggests that more effort could be made to involve legislatures and independent accountability institutions in the OGP itself and in open government initiatives generally. This could include, for example, increasing their awareness of OG initiatives and "socializing" them into the values of openness, as well as strengthening their capacity and to enact and enforce OG provisions, and to better use the information released by the government. Indeed, we could argue that an open government cannot exist without an open society - where everybody participates constructively in the production and consumption of information, regardless of whether they are part of the government or not. 


\section{References}

Ackerman, J. M., \& Sandoval-Ballesteros, I. E. (2006). The global explosion of freedom of information laws. Administrative Law Review, 58(1), 85-130.

Alt, J. E., \& Lassen, D. D. (2006). Fiscal transparency, political parties, and debt in OECD countries. European Economic Review, 50(6), 1403-1439.

Berliner, D. (2014). The Political Origins of Transparency. Journal of Politics, 76(2), 479-491.

Bolívar, M. P. R., Pérez, C. C., \& Hernández, A. M. L. (2006). Cultural contexts and governmental digital reporting. International Review of Administrative Sciences, 72(2), 269-290.

Bolívar, R., Pedro, M., Muñoz, L. A., \& Hernández, A. M. L. (2013). Determinants of financial transparency in government. International Public Management Journal, 16(4), 557-602.

Botero, J., Ponce, A., \& Shleifer, A. (2013). Education, Complaints, and Accountability. The Journal of Law \& Economics, 56(4), 959-996.

Brockmyer, B. I., \& Fox, J. (2015). Assessing the Evidence: The Effectiveness and Impact of Public Governance-Oriented Multi-Stakeholder Initiatives. London, UK: Open Society Foundation.

Center for American Progress. (2016). Let the Sunshine In. An Assessment of the Open Government Partnership. Center for American Progress. Washington, DC: Elgin-Cossart, M., Sutton, T., \& Sachs, K.

Cicatiello, L., De Simone, E., \& Gaeta, G. L. (2017). Political determinants of fiscal transparency: a panel data empirical investigation. Economics of Governance, 18(4), 315336. 
Darch, C., \& Underwood, P. G. (2010). Freedom of information and the developing world: The citizen, the state and models of openness. Oxford, UK: Chandos Publishing.

De Graaf, G., \& Paanakker, H. (2015). Good governance: Performance values and procedural values in conflict. The American Review of Public Administration, 45(6), 635-652.

Denhardt, R. B., \& Denhardt, J. V. (2000). The new public service: Serving rather than steering. Public administration review, 60(6), 549-559.

Diamond, L. (2015). Facing up to the democratic recession. Journal of Democracy, 26(1), 141155.

Djankov, S., La Porta, R., Lopez-de-Silanes, F., \& Shleifer, A. (2010). Disclosure by politicians. American Economic Journal: Applied Economics, 2(2), 179-209.

Etzioni, A. (2014). The limits of transparency. Public Administration Review, 74(6), 687-88.

Fairbanks, J., Plowman, K. D., \& Rawlins, B. L. (2007). Transparency in government communication. Journal of Public Affairs: An International Journal, 7(1), 23-37.

Fox, J. (2013, November 11). Speaking of International T/A Initiatives and CSO-Researcher Dialogue... [Think Piece] Transparency and Accountability Initiative. Retrieved from http://www.transparency-initiative.org/archive/news/talearn-annual-workshop

Fox, J. (2015). Social accountability: what does the evidence really say?. World Development, 72, 346-361.

Glaeser, E. L., Ponzetto, G. A., \& Shleifer, A. (2007). Why does democracy need education?. Journal of economic growth, 12(2), 77-99.

Grimes, M. (2013). The Contingencies of Societal Accountability: Examining the Link Between Civil Society and Good Government. Studies in Comparative International Development, 48(4), 380-402. 
Grimmelikhuijsen, S. G., \& Feeney, M. K. (2016). Developing and Testing an Integrative Framework for Open Government Adoption in Local Governments. Public Administration Review, 77(4), 579-590.

Grimmelikhuijsen, S. G., \& Welch, E. W. (2012). Developing and testing a theoretical framework for computer-mediated transparency of local governments. Public Administration Review, 72(4), 562-571.

Grzymala-Busse, A. (2006). The discreet charm of formal institutions: Postcommunist party competition and state oversight. Comparative Political Studies, 39(3), 271-300.

Hollyer, J. R., Rosendorff, B. P., \& Vreeland, J. R. (2014). Measuring transparency. Political analysis, 22(4), 413-434.

Hood, C., \& Heald, D. (Eds.). (2006). Transparency: The Key to Better Governance? New York: Oxford University Press.

Inglehart, R., \& Welzel, C. (2003). Political culture and democracy: Analyzing cross-level linkages. Comparative Politics, 36(1), 61-79.

Ingrams, A. (2018). Democratic transition and transparency reform: An fsQCA analysis of access to information laws in twenty-three countries. Government Information Quarterly.

Islam, R., \& Montenegro, C. E. (2002). What determines the quality of institutions?. The World Bank.

Kosack, S., \& Fung, A. (2014). Does transparency improve governance? Annual Review of Political Science, 17, 65-87.

La Porta, R., Lopez-de-Silanes, F., Shleifer, A., \& Vishny, R. (1999). The quality of government. Journal of Law, Economics, and Organization, 15(1), 222-279. 
Lee, C., Chang, K., \& Berry, F. S. (2011). Testing the development and diffusion of egovernment and e-democracy: A global perspective. Public Administration Review, 71(3), 444-454.

LeRoux, K. (2007). Nonprofits as civic intermediaries the role of community-based organizations in promoting political participation. Urban Affairs Review, 42(3), 410-422.

Lindstedt, C., \& Naurin, D. (2010). Transparency is not enough: Making transparency effective in reducing corruption. International political science review, 31(3), 301-322.

Marshall, M. G., Gurr, R. T., \& Jaggers, K. (2015). Polity IV project: Political regime characteristics and transitions, 1800-2015. Data user's manual. Center for Systemic Peace.

McCubbins, M. D., \& Schwartz, T. (1984). Congressional oversight overlooked: Police patrols versus fire alarms. American Journal of Political Science, 28(1), 165-179.

McDermott, P. (2010). Building open government. Government Information Quarterly, 27(4), 401-13.

Meijer, A. J., Curtin, D., \& Hillebrandt, M. (2012). Open government: connecting vision and voice. International Review of Administrative Sciences, 78(1), 10-29.

Michener, G. (2011). FOI laws around the world. Journal of Democracy, 22(2), 145-159.

Michener, G. (2015). Policy Evaluation via Composite Indexes: Qualitative Lessons from International Transparency Policy Indexes. World Development, 74, 184-196.

Moynihan, D. P. (2003). Normative and instrumental perspectives on public participation: Citizen summits in Washington, DC. The American Review of Public Administration, 33(2), 164-188. 
Nabatchi, T., \& Leighninger, M. (2015). Public participation for 21 st century democracy. John Wiley \& Sons.

Open Government Partnership (OGP). (2016, December). Results of Early Open Government Partnership Initiatives. Retrieved from http://www.opengovpartnership.org/sites/default/files/OGP_Early-Results_Dec2016.pdf

Open Government Partnership (OGP). (2018a). How To Join. Retrieved from: https://www.opengovpartnership.org/how-join\#sthash.hYTUQKQW.dpuf

Open Government Partnership (OGP). (2018b). About the IRM. Retrieved from: https://www.opengovpartnership.org/about/independent-reporting-mechanism/about-irm

Open Government Partnership (OGP). (2012, June). Open Government Partnership: Articles of Governance (updated March 2014 and April 2015). Retrieved from: https://www.opengovpartnership.org/sites/default/files/attachments/OGP_ArticlesGov_Apr-21-2015.pdf

Ortiz-Rodríguez, D., Navarro-Galera, A., \& Alcaraz-Quiles, F. J. (2015). The Influence of Administrative Culture on Sustainability Transparency in European Local Governments. Administration \& Society, 50(4), 555-594.

Pasquier, M., \& Villeneuve, JP. (2007). Organizational barriers to transparency a typology and analysis of organizational behaviour tending to prevent or restrict access to information. International Review of Administrative Sciences, 73(1), 147-162.

Piotrowski, S. J. (2008). Governmental transparency in the path of administrative reform. Albany: State University of New York Press. 
Piotrowski, S. J. (2017). The "Open Government Reform” Movement: The Case of the Open Government Partnership and US Transparency Policies. The American Review of Public Administration, 47(2), 155-171.

Putnam, R. D. (2001). Bowling alone: The collapse and revival of American community. New York: Simon and Schuster.

Rios, A.M., Bastida, F., \& Benito, B. (2014). Budget Transparency and Legislative Budgetary Oversight. An International Approach. The American Review of Public Administration, $46(5), 546-568$.

Roberts, A. S. (2006). Blacked out: Government secrecy in the information age. Cambridg, UK: Cambridge University Press.

Roberts, A. S. (2012). WikiLeaks: the illusion of transparency. International Review of Administrative Sciences, 78(1), 116-133.

Roberts, A. S. (2015). Too Much Transparency? How Critics of Openness Misunderstand Administrative Development. Prepared for the Fourth Global Conference on Transparency Research. Università della Svizzera italiana.

Serra, A. (2011). A Short Treatise on the Wealth and Poverty of Nations (1613). Anthem Press.

Skocpol, T. (2013). Diminished Democracy: From Membership to Management in American Civic Life (Vol. 8). University of Oklahoma Press.

Teorell, J., Dahlberg, S., Holmberg, S., Rothstein, B., Khomenko, A., \& Svensson, R. (2016). The Quality of Government Standard Dataset, version Jan16. [Data file]. University of Gothenburg: The Quality of Government Institute.

Torres, L. (2004). Trajectories in public administration reforms in European Continental countries. Australian Journal of Public Administration, 63(3), 99-112. 
Weber, M. (1978). Economy and society: An outline of interpretive sociology. Berkeley, CA: University of California Press.

Wehner, J., \& De Renzio, P. (2013). Citizens, legislators, and executive disclosure: The political determinants of fiscal transparency. World Development, 41, 96-108.

Welch, E. W., \& Wong, W. (2001). Global information technology pressure and government accountability: The mediating effect of domestic context on website openness. Journal of Public Administration Research and Theory, 11(4), 509-538.

Williams, A. (2009). On the release of information by governments: Causes and consequences. Journal of Development Economics, 89(1), 124-138.

Williams, A. (2015). A global index of information transparency and accountability. Journal of Comparative Economics, 43(3), 804-824.

Wong, W., \& Welch, E. W. (2004). Does e-government promote accountability? A comparative analysis of website openness and government accountability. Governance, 17(2), 275297.

Worthy, B. (2015). The Impact of Open Data in the UK: Complex, Unpredictable, and Political. Public Administration, 93(3), 788-805.

Zyl, A. (2014). How civil society organizations close the gap between transparency and accountability. Governance, 27(2), 347-356.

\section{Footnotes}

\footnotetext{
${ }^{\mathrm{i}}$ The OGP Steering Committee includes eleven government and eleven civil society representatives from member countries, on a rotating basis. The members are elected every three years by all OGP members (OGP, 2012).
} 


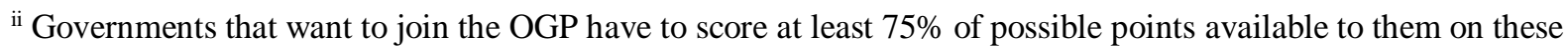
criteria.

iii As Meijer, Curtin and Hillebrandt (2012) point out, openness is both about vision - i.e., whether citizens can "see" what is going on within government (transparency), and about voice - i.e., whether citizens have access to decisionmaking arenas (participation). A third frequently named aspect of openness is collaboration (Grimmelikhuijsen and Feeney, 2016). Yet, collaboration between government and citizens, e.g. in the "co-production" of services or public goods is arguably also a form of participation. Openness is also tied to the increased use of technology by governments to communicate with and involve citizens in public affairs (Wirtz and Birkmeyer, 2015). But technology is a tool. It can expand existing avenues for information and communication, but whether a government is more or less open depends on how frequently and how well these tools are used to increase transparency and participation.

${ }^{\text {iv }}$ Correlation coefficients between the share of OGP points on all eligibility criteria and various alternate transparency or openness measure range from 0.5617 to 0.74 , all of which are statistically significant.

${ }^{v}$ Divided government can occur both in two-party and in multi-party systems, if the legislature is controlled by a different party than the executive, as is the case, for example, of minority governments in parliamentary multi-party systems.

${ }^{v i}$ http://www.opengovpartnership.org/irm/ogp-explorer-and-irm-data

vii Since the data is available for only one year (2008), we used the same values for all the years from 2011 to 2015.

viii We reverse-code the scale, which ranges from 0 (most free) to 100 (least free), for easier interpretation of results.

${ }^{i x}$ As some of our dependent variables are discrete, we ran ordered logit models, but most results remain the same. Hence, we report results from OLS regressions in the paper for easier interpretations and consistency across different models.

${ }^{\mathrm{x}}$ We conducted the Chow test (i.e. poolability test), which suggests that we can use the pooled OLS. 


\section{Tables}

\section{Table 1. OGP Eligibility Criteria}

\begin{tabular}{ll} 
OGP Criterion & Scoring \\
\hline Budget & Two points each for publication of (i) \\
Transparency & Executive's Budget Proposal, and (ii) Audit \\
(BT) & Report.
\end{tabular}

Original Data Source

Open Budget Index (OBI)

from the International Budget

Partnership (IBP)

http://www.internationalbudg

et.org/opening-budgets/open-

budget-initiative/open-

budget-survey/

\begin{tabular}{|c|c|c|}
\hline $\begin{array}{l}\text { Access to } \\
\text { Information } \\
(\mathrm{ATI})\end{array}$ & $\begin{array}{l}4 \text { points for access to information laws } \\
\text { (FOIAs), } 3 \text { points if a country has a } \\
\text { constitutional provision guaranteeing } \\
\text { access to information, and } 1 \text { point for a } \\
\text { draft access to information law under } \\
\text { consideration. Countries with both a } \\
\text { constitutional provision and a draft law can } \\
\text { only be awarded } 3 \text { points. }\end{array}$ & $\begin{array}{l}\text { The Right to Information } \\
\text { (RTI) } \\
\text { http://right2info.org/ }\end{array}$ \\
\hline $\begin{array}{l}\text { Asset } \\
\text { Disclosure } \\
\text { (AD) }\end{array}$ & $\begin{array}{l}4 \text { points for an officials' asset disclosure } \\
\text { law requiring public access, } 2 \text { for a law } \\
\text { requiring (non-public) disclosure, } 0 \text { points } \\
\text { for no law. }\end{array}$ & $\begin{array}{l}\text { World Bank's Public } \\
\text { Officials Financial Disclosure } \\
\text { database } \\
\text { http://publicofficialsfinancial } \\
\text { disclosure.worldbank.org/ }\end{array}$ \\
\hline \multirow[t]{2}{*}{$\begin{array}{l}\text { Citizen } \\
\text { Engagement/ } \\
\text { Civil Liberties } \\
\text { (CL) }\end{array}$} & $\begin{array}{l}4 \text { points for countries scoring above } 7.5 \text { on } \\
\text { the EIU's Civil Liberties score of } 1-10 ; 3 \\
\text { for scoring above } 5 ; 2 \text { points above } 2.5 ; 0 \\
\text { otherwise. }\end{array}$ & $\begin{array}{l}\text { Economic Intelligence Unit's } \\
\text { (EIU) Democracy Index - } \\
\text { Civil Liberties sub-indicator } \\
\text { http://www.eiu.com/public/th } \\
\text { ankyou_download.aspx?activ }\end{array}$ \\
\hline & $\begin{array}{l}\text { The index captures issues such: the } \\
\text { existence of a free press (ca. } 5 \text { indicators), } \\
\text { freedom of association and petition, and } \\
\text { various aspects of the rule of law } \\
\text { (independent judiciary, equal treatment } \\
\text { under the law, protection of property rights, } \\
\text { and respect for human rights). }\end{array}$ & $\begin{array}{l}\text { ity=download\&campaignid }= \\
\underline{\text { Democracy0115 }}\end{array}$ \\
\hline
\end{tabular}

Source: Authors, based on http://www.opengovpartnership.org/how-it-works/eligibility-criteria 
Table 2. Summary Statistics

\begin{tabular}{|l|c|c|c|c|c|}
\hline Variable & Obs & Mean & Std. Dev. & Min & Max \\
\hline Share of OGP Eligibility Points & 605 & 0.74 & 0.26 & 0.06 & 1.00 \\
\hline OGP Budget Transparency & 404 & 3.24 & 1.26 & 0.00 & 4.00 \\
\hline OGP Access to Information & 605 & 2.92 & 1.57 & 0.00 & 4.00 \\
\hline OGP Asset Disclosure & 592 & 2.86 & 1.22 & 0.00 & 4.00 \\
\hline OGP Civil Liberties & 605 & 3.15 & 0.96 & 1.00 & 4.00 \\
\hline Political Competition & 605 & 0.33 & 0.18 & 0.00 & 0.92 \\
\hline Executive Constraints & 605 & 5.39 & 1.82 & 1.00 & 7.00 \\
\hline Anglo-Saxon Administrative Tradition & 605 & 0.29 & 0.45 & 0.00 & 1.00 \\
\hline Bureaucratic Quality & 605 & 2.27 & 1.04 & 0.00 & 4.00 \\
\hline GSOs per capita, logged & 605 & 1.99 & 1.35 & -2.02 & 4.37 \\
\hline Press Freedom & 605 & 50.44 & 22.63 & 5.00 & 91.00 \\
\hline Educational Attainment & 605 & 8.83 & 3.47 & 1.14 & 14.73 \\
\hline GDP per capita, logged & 605 & 8.86 & 1.47 & 5.76 & 11.67 \\
\hline Population, logged & 605 & 16.48 & 1.52 & 13.16 & 21.04 \\
\hline Index of Globalization & 605 & 66.04 & 13.15 & 31.98 & 90.24 \\
\hline
\end{tabular}


Table 3. Results for OGP Measures of Openness

\begin{tabular}{|c|c|c|c|c|c|}
\hline & $\begin{array}{l}\text { Share of } \\
\text { OGP } \\
\text { Eligibility } \\
\text { Points }\end{array}$ & $\begin{array}{l}\text { Budget } \\
\text { Transparency }\end{array}$ & $\begin{array}{l}\text { Access to } \\
\text { Information }\end{array}$ & $\begin{array}{l}\text { Asset } \\
\text { Disclosure }\end{array}$ & $\begin{array}{l}\text { Civil } \\
\text { Liberties }\end{array}$ \\
\hline \multirow[t]{2}{*}{$\begin{array}{l}\text { Political } \\
\text { Competition }\end{array}$} & 0.108 & 0.658 & 0.748 & 0.253 & 0.342 \\
\hline & $(0.077)$ & $(0.588)$ & $(0.565)$ & $(0.457)$ & $(0.230)$ \\
\hline \multirow{2}{*}{$\begin{array}{l}\text { Executive } \\
\text { Constraints }\end{array}$} & $0.074 * * *$ & $0.217 * * *$ & $0.304 * * *$ & $0.285^{* * *}$ & $0.314 * * *$ \\
\hline & $(0.010)$ & $(0.082)$ & $(0.071)$ & $(0.067)$ & $(0.032)$ \\
\hline \multirow{2}{*}{$\begin{array}{l}\text { Anglo-Saxon } \\
\text { Admin. Trad. }\end{array}$} & -0.007 & 0.265 & -0.214 & -0.151 & 0.092 \\
\hline & $(0.029)$ & $(0.227)$ & $(0.221)$ & $(0.213)$ & $(0.098)$ \\
\hline \multirow[t]{2}{*}{$\begin{array}{l}\text { Bureaucratic } \\
\text { Quality }\end{array}$} & -0.025 & -0.111 & -0.144 & 0.082 & -0.032 \\
\hline & $(0.018)$ & $(0.146)$ & $(0.145)$ & $(0.128)$ & $(0.071)$ \\
\hline \multirow[t]{2}{*}{$\begin{array}{l}\text { CSOs per capita, } \\
\text { logged }\end{array}$} & $0.040 * * *$ & $0.242 * *$ & 0.182 & -0.007 & $0.187 * * *$ \\
\hline & $(0.014)$ & $(0.095)$ & $(0.118)$ & $(0.093)$ & $(0.040)$ \\
\hline \multirow[t]{2}{*}{ Press Freedom } & $0.0005^{* *}$ & -0.001 & $0.005^{* *}$ & 0.0001 & $0.002 *$ \\
\hline & 0.000 & $(0.002)$ & $(0.002)$ & $(0.001)$ & $(0.001)$ \\
\hline \multirow{2}{*}{$\begin{array}{l}\text { Educational } \\
\text { Attainment }\end{array}$} & $0.030 * * *$ & $0.131 * *$ & $0.180 * * *$ & $0.139 * * *$ & $0.051 * *$ \\
\hline & $(0.007)$ & $(0.056)$ & $(0.053)$ & $(0.044)$ & $(0.021)$ \\
\hline \multirow[t]{2}{*}{$\begin{array}{l}\text { GDP per capita, } \\
\text { logged }\end{array}$} & $-0.044 * *$ & -0.242 & $-0.321 * *$ & $-0.274^{*}$ & 0.074 \\
\hline & $(0.018)$ & $(0.146)$ & $(0.149)$ & $(0.148)$ & $(0.063)$ \\
\hline \multirow[t]{2}{*}{$\begin{array}{l}\text { Population, } \\
\text { logged }\end{array}$} & $0.059 * * *$ & $0.158 * *$ & $0.422 * * *$ & $0.151 * *$ & $0.065^{*}$ \\
\hline & $(0.013)$ & $(0.077)$ & $(0.095)$ & $(0.075)$ & $(0.039)$ \\
\hline \multirow[t]{2}{*}{$\begin{array}{l}\text { Index of } \\
\text { Globalization }\end{array}$} & $0.004 *$ & $0.029 *$ & 0.017 & 0.008 & 0.000 \\
\hline & $(0.002)$ & $(0.017)$ & $(0.017)$ & $(0.016)$ & $(0.006)$ \\
\hline \multirow[t]{2}{*}{ (Constant) } & $-0.884 * * *$ & -2.059 & $-6.213 * * *$ & -0.924 & -1.203 \\
\hline & $(0.273)$ & $(1.842)$ & $(1.886)$ & (1.598) & $(0.803)$ \\
\hline R-Squared & 0.721 & 0.4153 & 0.4996 & 0.4432 & 0.7653 \\
\hline $\mathrm{N}$ & 605 & 404 & 605 & 592 & 605 \\
\hline
\end{tabular}

Notes: Clustered standard errors in parentheses; Year dummies included but not reported Two-tailed tests of significance; $* \mathrm{p}<0.10, * * \mathrm{p}<0.05, * * * \mathrm{p}<0.01$ 


\section{Appendix A. List of countries in the sample}

\begin{tabular}{|c|c|c|c|}
\hline Albania & Egypt & Latvia & Qatar \\
\hline Algeria & El Salvador & Lebanon & Romania \\
\hline Angola & Estonia & Liberia & Russia \\
\hline Argentina & Ethiopia & Lithuania & Saudi Arabia \\
\hline Armenia & Finland & Luxembourg & Senegal \\
\hline Australia & France & Madagascar & Sierra Leone \\
\hline Austria & Gabon & Malawi & Singapore \\
\hline Azerbaijan & Gambia & Malaysia & Slovakia \\
\hline Bahrain & Germany & Mali & Slovenia \\
\hline Bangladesh & Ghana & Mexico & South Africa \\
\hline Belarus & Greece & Moldova & Spain \\
\hline Belgium & Guatemala & Mongolia & Sri Lanka \\
\hline Bolivia & Guinea-Bissau & Morocco & Suriname \\
\hline Botswana & Guyana & Mozambique & Sweden \\
\hline Brazil & Honduras & Myanmar & Switzerland \\
\hline Bulgaria & Hungary & Namibia & Syria \\
\hline Burkina Faso & India & Netherlands & Tanzania \\
\hline Cameroon & Indonesia & New Zealand & Thailand \\
\hline Canada & Iran & Nicaragua & Togo \\
\hline Chile & Iraq & Niger & Trinidad and Tobago \\
\hline China & Ireland & Nigeria & Turkey \\
\hline Colombia & Israel & Norway & Uganda \\
\hline Congo & Italy & Pakistan & Ukraine \\
\hline Costa Rica & Jamaica & Panama & United Arab Emirates \\
\hline Croatia & Japan & Papua New Guinea & United Kingdom \\
\hline Cuba & Jordan & Paraguay & United States \\
\hline Cyprus & Kazakhstan & Peru & Uruguay \\
\hline Czech Republic & Kenya & Philippines & Venezuela \\
\hline Denmark & Korea, South & Poland & Vietnam \\
\hline Dominican Republic & Kuwait & Portugal & Zambia \\
\hline Ecuador & & & \\
\hline
\end{tabular}

